\title{
Different values lead to alternative approaches to the land debate in South Africa
}

\section{Das Steÿn}

\section{DOI: $h$ ttp://dx.doi.org/10.18820/2415-0495/trp75i1.11}

Peer reviewed and revised October 2019; Published December 2019

${ }^{*}$ The author declared no conflict of interest for this title or article

\begin{abstract}
In South Africa, two traditional cultures, namely the African and the European cultures, meet, each with its own historical view on what land is and how to govern it. This situation is complicated by modernist ideological thinking represented by capitalism and communism. Goudappel's urbanistic concept ${ }^{1}$ is used to show how ideological thinking influences theory and practice when contemplating the land issue. This answer is not a single approach, but a multiple view on land which allows for different regions, each with its own solution coupled with its cultural background, in order for all the different peoples in this country to have a place in the sun. Therefore, this article gives a theoretical explanation that there are different value systems that influence the approach to possible solutions of the land issue in South Africa.
\end{abstract}

Keywords: Autonomous regions or city states, land debate, modernist thinking, South Africa, traditional values

\section{VERSKILLENDE WAARDES LEI TOT ALTERNATIEWE BENADERINGS TOT DIE GRONDDEBAT IN SUID-AFRIKA}

In Suid-Afrika het die Europese- en die Afrika-tradisie mekaar ontmoet. Elkeen het 'n eie historiese beskouing van grondbesit en hoe om dit te bestuur. Met die opkoms van die modernistiese ideologiese denke is hierdie siening oor grond beïnvloed deur onderskeidelik kapitalisme en kommunisme. Goudappel se Urbanistiek Konsep sal gebruik word om aan te toon hoe ideologiese denke die teoretiese denke maar ook die praktiese denke oor grond oorheers. Die oplossing lê nie in 'n enkele beleid oor grond nie, maar in 'n verskeidenheid van verskillende streke waar elk met 'n eie oplossing na vore kom wat pas by die kulturele agtergrond van die verskillende volke in hierdie land om vir elkeen 'n plekkie in die son te besorg. Hierdie artikel is dus 'n teoretiese uiteensetting dat daar verskillende waardesisteme is wat die benadering tot moontlike oplossings van die grondkwessie in Suid-Afrika beïnvloed.

Sleutelwoorde: Grondkwessie in Suid-Afrika, modernistiese denke, onafhanklike streke of stadstate, tradisionêle waardes

\section{LITUMELO TSE FAPANENG LI TLISA MEKHOA E MECHA EA HO LEKOLA LIPUISANO TSE AMANANG LE LEFATSHE NAHENG EA AFRIKA BORWA}

Naheng ea Afrika Borwa, meetlo e mmeli ea ma-Afrika le ma-Europe e kopane, mme moetlo ka mong o ikemetse nthleng ea kutloisiso le tsamaiso ea lefatshe. Maemo ana

1 In the 1960s, Goudappel began his search for meaning in the field of traffic engineering. When appointed as professor at the Technical University of Eindhoven in 1970, he developed the Urbanistic Concept (Steÿn, 2011: 1-13) a thatafatsoa ke mokhoa oa boinahana oa kajeno, o iponahatsang ka bokapitale le bokomonisi. Mehopolo ea Litoropo ea Goudappel e sebelisitsoe ho bontsha hore boinahano bo ka susumetsa mekhoa le meetlo e amanang le lefatshe. Karabo ena hase eona fela e ka fanoang, kaha hona le maikutlo a mangata mabapi le taba ea lefatshe, a bileng a thusang libaka ka ho fapana ho fihlela litharollo ho latela maemo le meetlo ea tsona e ikhethileng, ele hore batho ka ho fapana hoa bona ba fumane sebaka sa tulo. $\mathrm{Ka}$ hona, sengoliloeng sena se fana ka thlaloso ea hore hona le mekhoa e fapaneng e susumetsang litharollo tse tlisoang mathateng a shebaneng le lefatshe naheng ea Afrika Borwa.

\section{INTRODUCTION}

In the southern part of Africa, two cultural traditions confronted each other on the issue of land. The main players are the African ${ }^{2}$ cultures that share a common kind of background, as they all derive from roughly $1000 \mathrm{BC}$ from a common area in Central West Africa (Diamond, 2006: 388) and the Western culture introduced by the Dutch and the English (Steÿn, 2015: 238-260).

A third view on land, namely that of modern-day utopian thinking preached by humanism with its two siblings, capitalism and communism, has a strong influence on both traditions. For the purpose of this article, these two groups that reject traditional thinking will be grouped together as modernists. Thus, both the African idea of communal ownership of land and the Western idea of private property are under pressure to change from the 'noncultural' way of viewing the world. Goudappel's (1985) urbanistic concept, which distinguishes

2 In this article, African culture will refer mostly to the Bantu-speaking Black population of South Africa and will not include the Khoikhoi or the San. Their claim to land as being the "first indigenous people of South Africa" will have to be dealt with differently. They were herders and hunters, respectively, who did not settle in one place for a long period of time and who were pushed from the land by both Black and White settlers.

Prof. Das Steÿn, Research Fellow, Department of Urban and Regional Planning, University of the Free State, P O Box 392, Bloemfontein, South Africa. Phone 051 4012893, e-mail: <steynjj@ufs.ac.za> 
between three levels of thinking, namely ideological, theoretical and practical, will be used as a means to understand and unravel the land issue that is presently in the limelight in South Africa.

\section{GOUDAPPEL'S URBANISTIC CONCEPT AS METHODOLOGICAL APPROACH}

After the 1968/1969 student revolution in Europe, it was very difficult to discuss subjects at university, because anything immediately became a political issue and all other dialogues were pushed aside. In response to this, Goudappel (1985: 179-180) developed the urbanistic concept as "a systematic inventory and classification of the elements that rule our active interventions through physical planning and as a vehicle for understanding the patterns in man's relationship with his environment".

With this concept, Goudappel distinguishes between the world of thinking and the world of doing. $\mathrm{He}$ found that there are three levels of thinking: ideological, theoretical and practical. The question 'why' relates to values underlying this issue; the question 'how' relates to the realm of the theory, and when the question 'what' is answered, the problem is mostly on the practical level (Steÿn, 2011: 2). Goudappel lists these three levels as the ideostructure, the superstructure, and the infrastructure levels of thinking, respectively. For him (Goudappel 1985: 180), "the infrastructure is the physical appearance of things and phenomena, the superstructure being theorizing and organizational thinking and the ideostructure dealing with the ideals and values which direct human activities". This means that no viewpoint, theory or action is value free.

This concept will be used to understand South Africans' thinking and discussing the land issue. One cannot argue about ideological differences, which are value issues. How can one tell somebody to believe in something else? On the theoretical level, one can argue about practical issues and compare different solutions. On the practical side, one can put the real issue on the table and discuss it in depth. This article is thus one traditional Christian Afrikaner's ${ }^{3}$ view on the issue of land as there are no objective approaches to land, according to Goudappel.

\section{SOME THOUGHTS ON TRADITIONALISM AND MODERNISM}

Baudet \& Visser (2017: 9) found that traditionalists (conservatives) believe that society should focus on the sociocultural conditions of political freedom and the religious roots of human experience.

This type of solution focuses on the human being as part of a greater whole. Modernists favour a political philosophy based on human thought on progress, reform, and the protection of civil liberties. They focus mainly only on one aspect of human life - freedom. For them, the State is the vehicle that will produce the utopian society. For the liberals, freedom will come through the individual's freedom to participate in a capitalist free market system that the State must guarantee, and that offers equal opportunities to all. For the communist, it is a freedom where the State will provide equality and brotherhood of all citizens, and where "the individuals obtain their freedom in and through their association" with the real communist community (Marx \& Engels, 1989b: 68).

For the traditionalists Baudet \& Visser (2017: 10), it is about the responsibility of the individual in society for the well-being of the cultural environment, the human measure in an industrial mass society, integrity, the social conditions for the constitutional State, and the protection of the environment. It is not about a new religion that evaluates the present from abstract ends in society, but one

3 Other traditional Afrikaners might differ from this view, as modern Afrikaners have a variety of value systems. that views present and past issues that are important for the cultural well-being of man and society.

The Cambridge Advanced Learner's Dictionary (Walter, 2009:1544) defines tradition as "a belief, principle or way of acting which people in a particular society or group have continued to follow for a long time, or all these beliefs etc. in a particular society or group". Culture is defined as "the way of life, especially the general customs and beliefs, of a particular group of people at a particular time". A traditionalist is "someone who believes in and follows the traditional ideas". According to this dictionary, modern is "of the present or recent times, especially the period of history since the middle ages". For communism, it is a call for the freedom, equality and brotherhood of all citizens which the State will provide. For capitalism, it is the freedom for each individual to participate in an open market.

\section{LEVELS OF THINKING}

\subsection{Ideological thinking on land (ideostructure): Why people think differently}

In South Africa, the modern ideology of liberalism and capitalism influences both the African and the Western traditional thinking on the land issue. Van Niekerk (1993b: 3) found that many Black and White South Africans avoid facing the deeply embedded differences between the African and the Western world views and warned that "unless we recognise and acknowledge them, we cannot hope to develop the skills to handle them".

In Africa, the Bantu-speaking group (including Southern Africa's Blacks) can be distinguished from other language population groups in Africa such as the Niger-Congo, Hamites, Nilotic, Semitic, Khoikhoi, San and Westerners, on linguistic and cultural grounds (Pauw, 1970: 49). For traditional Bantu-speaking Africans, land is sacred, because it belongs to the earth spirit as well as to the ancestors and the living (Van der Borght, 2009: 2). The land is ruled by chiefdoms whose head 
is a chief; he is responsible for the good government of the tribe and for the control of land. He can directly approach the tribal ancestors, spirits of dead chiefs. This means that land cannot be sold or disposed of without the consent of the whole family, and the whole family includes the living, the spirits of the ancestors, and the unborn (Van Niekerk, 1993a).

In the West, all the people who were once under the rule of the Roman Empire were subject to the codification of Roman Law through the Lex Duodecim Tabularum, ${ }^{4}$ which contained rules of private, public and procedural law in $450 \mathrm{BC}$ and was used for the next 600 years (Bouckaert, 2010: 9). This set the way of thinking in the West that owning property concerns ownership and possession of things, which could be movables or immovables (Bouckaert, 2010: 10-12).

This distinction between absolute right that can be defended against everybody and relative rights that can only be invoked against a specific person influenced even modern European mainland law, on which South African law is based, especially Roman Dutch Law. For Christians, the ownership and the use of land are deeply related to man's calling to stewardship of land. For Vorster (Van der Borght, 2009: 92), ownership and stewardship are two sides of the same coin.

Modernist thought is represented, on the one hand, by the individual thinking of the capitalist, who views land as an asset that can be used and developed to produce a profit for the owner. On the other hand, communism sees land as a means of production that should be in the hands of the State. Both these groups have a utopian vision of the future where everybody is in a better socio-economic position in a global world and there is a belief in cultural relativism. The one group is mostly driven by greed and the other by need.

4 Law of the Twelve Tables (450BC) was the first codification in Roman Law and formed the basis for Roman Law for nearly 1000 years (Bouckaert, 2010: 9).
For economists, the powers conveyed by ownership of land are "the powers to use and manage the land, powers to transfer or alienate it, and powers to take the income or rent from its use" (Scott, 2008: 5). Different kinds of property rights such as rights over mineral resources, rights over fugacious resources, and rights over wood-based resources can be associated with ownership. Although capitalism has been refined since the time of Adam Smith, John Locke and David Ricardo, many economists still "view land as simply one of the means of production, subject to the same laws of the market as any other input" (McCusker, Moseley \& Ramutsindela, 2016: 17).

On the other hand, Frederick Engels (Marx \& Engels, 1989a: 92), in his Principles of communism, writes that "private ownership will also have to be abolished", while Marx (Marx \& Engels, 1989a: 125) states that "the theory of Communism may be summed up in the single sentence: 'Abolition of private property'. Through State ownership of property and "State capitalism", workers of the world communist regimes benefited little from economic development; only the elite profited (Vorhies, 1991: 100).

\subsection{Theoretical thinking on land (superstructure): How people think differently}

According to Vorster (in Van der Borght, 2009: 82), Africans traditionally do not relate to the concept of individual land ownership that excludes other people from any landholding in private land. The right of the community to the property is regarded as of more value than the individual rights. Van der Borght (2009: 2) found that, for traditional African people, land is owned by God. Land cannot be traded as private property, nor for the State to control, but rather for the control by local chiefs.

Van Niekerk (1993b: 35) refers to the Nigerian Nobel prize winner Wole Soyinka who wrote that the "recognisable Western cast of mind, a compartmentalising habit of thought" contrasts with the "assimilative wisdom of African metaphysics". Westerners think analytically (A and non-A cannot be the same), while in the tradition of Africa opposites are not mutually exclusive. The living and the dead are connected in ways that the West does not understand.

In a book based on his DD thesis, Dominee, are you listening to the drums?, Van Niekerk (1982) shows that rational conclusions do not always play in the minds of people; there are also "those deep, often irrational - or extra-rational surgings which one sees functioning in the life of states, nations and groups" (Van Niekerk, 1982: 1). Black poetry of the 1970 s shows how "some poets reject the White city while maintaining a deep affinity with the Black township, even in its suffering and misery" (Van Niekerk, 1982: 110). Modern thinking has changed traditional thinking and a considerable variety of thought on land can be distinguished among the African people.

White South African traditionalists, especially Afrikaners, view ownership and possession of things (including property) as an absolute right that can be defended against everybody. The South African law on property was taken over from the Roman and Roman-Dutch laws on property (Bouckaert, 2010: 10; Hunt, 1973: 152). This juridical approach to land was tempered by die Christian approach where man as landowner is viewed as a steward of God who is the absolute owner of the earth (Verbrugh, 1985: 17; Nijkamp, 1980: 14-150). The individual now has the responsibility to look after the land and pass it on to future generations in a sustainable fashion (Beatley, 1994: 4-145). Land is thus viewed as the personal responsibility of a steward.
Although all capitalist theorists support the idea of a free market, they differ on its operation. For Smith and Ricardo, it was about individual rights, while Lock also considered the labour theory of property (McCusker et al., 2016: 13-14). 
For the latter, the right to land was mediated by production for the market (Beatley, 1994: 192). In the 1970s, neoliberal thinking was behind the cure for the ailing economy of that time, with their turn to the market deregulation and free trade as the solution to all problems (McCusker et al., 2016: 16). Since then, the World Bank (WB) and the International Monetary Fund (IMF) would be key players on how countries must develop their economies, with the emphasis on private ownership of land.

In the communist world, Lenin elaborated on Marx's work on peasantry and believed that they could be primary suppliers of food. $\mathrm{He}$ also elaborated on the concept of differentiated peasantries (McCusker et al., 2016: 19). Trotsky was suspicious of the peasants because of their individualism (McCusker et al., 2016: 21). Stalin cut this theory formulation on the role/ position of the peasants short by his forced collectivisation from 1929 to the late 1930s. In South Africa, Bundy (1988) elaborated on the topic of the peasantry. The last two groups want to solve the problem on a global scale.

\subsection{Practical thinking on land (infrastructure): What people think differently}

One of the modern so-called "urban legends" is that all Whites are colonists or settlers. In reality, both Whites and Blacks are settlers. The United Nations (UN) has designated the Khoi and the San as the first indigenous nations in South Africa (Steÿn, 2015: 226). Because people elect to view history from a chosen perspective, it is not all that easy to determine what the truth of the matter is. It will mean various things to various people.

The two traditional thinkers on land possess the largest proportion of the land in South Africa. This occurred mostly by taking possession of any land not cultivated by indigenous peoples to be considered terra nullius, no-man's-land, conquering land or buying land. In terms of present thinking, different groups may question the transactions, but, according to international law, the land was mostly lawfully acquired.

Each of the two modernist groups have a different view on how land should be reformed in South Africa. For the capitalist-oriented group, all land must be in private hands. This led to clashes with the traditional leaders, especially the Zulu king, who will not give up their land. For the socialists, the Freedom Charter of 1955 calls for "land to be shared among those who work it" (DoE, 2005: 12). Some revolutionaries believe that the land belongs to the Blacks, and ignore the disputed historical development of South Africa (Kruger, 2016).

Capitalism has moved from nationalist capitalism to international capitalism. The WB and the IMF sold the idea that a global free market and open borders would solve all economic problems. Gone are the days when, according to Adam Smith in his 1776 book The wealth of nations, capitalism was viewed as a competitive free market with no participant in the position to dominate the market.

On the international scene, capitalism produced a large number of millionaires and a number of billionaires who own property and businesses in their country of origin. This later developed into international capitalism, and multinational companies started to dominate markets. However, in the 1980s, a new kind of billionaire emerged, the oligarchs who have no shareholders or home nation and are "internationalized beyond any nation states' wildest dreams" (Armstrong, 2010: 230). They "reshaped public discourse through well-funded think tanks and media empires, as well as increasing influence within universities" (Mcquaig \& Brooks, 2013: 96). Most of them do not stay in any country long enough to pay income tax or they evade income tax by putting their money in tax havens.
Neither is democracy or dictatorship a hindrance for these new global oligarchs. They use the babblers (politicians) as a front not only to do their dirty work, but also to protect them (Steÿn, 2014: 270-271).

Oxfam (2016) calculated that:

- In 2015, merely 62 individuals had the same wealth as 3.6 billion people - the bottom half of humanity.

- $\quad$ This figure is down from 388 individuals as recently as 2010 .

- The wealth of the richest 62 people has risen by $44 \%$ in the five years since 2010 - that is an increase of over half a trillion dollars (\$542bn) to \$1.76trillion.

- In 2017, Oxfam calculated that, at present, merely eight people own the same wealth as half the world's population.

The rich are getting richer and the poor are getting poorer (even in the Western world and in communist countries). Capitalism and communism have no meaning in the world of the super-rich.

Communism started off as anarchistic, with people such as Kropotkin and Boukanin who did not believe in private property, but only wanted to overthrow the present regime (Van den Berg, 1989: 137-149). Castells (1992: 73-75) argues that communism failed in Russia, because it could not deliver the goods it promised. China moved from being a communist country that opposed capitalism to one that embraces property rights, profits, and free-market competition, but does not respect human rights. Only a few poor communist or communist-influenced states still survive. In Cuba, the average monthly salary is roughly $\$ 30$ (R450) and, in Venezuela, the inflation rate is 10 million \% (IMF, 2019). At a conference in London, Prof. Robert Compton (2018) found that there are roughly 3.5 million Zimbabweans in South Africa (half a million legal and three million illegal). The general well-being in these countries that do not respect private ownership of land is thus not very high. 


\section{OTHER ISSUES IN THE LAND DEBATE}

The real issues to be addressed in South Africa are not land reform, but poverty and how to solve it. After 25 years of governance and due to the failure to deliver their promises, the ANC uses other issues to distract the voters in South Africa. This section deals with a few issues that should be mentioned in the debate on land.

\subsection{Poverty}

The most important issue to be addressed in South Africa is poverty. Poverty will not be solved if land is expropriated without compensation. In a paper dealing with power and corruption in South Africa at the 2014 SAPI conference, Steÿn (2014: 268) showed that the vast majority of people do not get out of poverty, due to abuse or betrayal by people with political and financial power.

For Jacobs (1985: 34), the basics for getting out of poverty are urbanisation and education. The African National Congress (ANC) government failed in both, as people urbanising only became urban poor without jobs, mostly on social grants. In his 1978 book I write what I like, Steve Biko showed that there is a relationship between reading, understanding the world, and being able to change the world (Aitchison, 2018). In this same article, Aitchinson refers to a Progress in International Reading Literacy Study (PIRL) 2016 literacy test on 13000 South African Grade 4 children that found that South Africa scored last of the 50 countries tested. At university level in 2017, the statisticiangeneral, Pali Lehohla, found that "the proportion of black students progressing at universities was higher in the 1980s than it was in 2017" (Gumede, 2017). At both school and university level, Blacks are worse off after 25 years of ANC education.

For Hall (2002: 8), the solution for South African cities with informal hyper-growth "is that the urban economy fails to keep pace with the population growth". His solution is "First to get the birth rate down, ${ }^{5}$ which means education, above all education for girls" (Hall, 2002: 8). Steÿn (2014: 274) elaborated on this issue and on how Brazil brought its fertility rate down.

\subsection{Governance}

Mthethwa (2013: 2-3) found that bribery, fraud and embezzlement are the most common forms of corruption. People experience lack of service delivery on all levels of life, while politicians make promises and shift the blame. Turok (2019: 222) found that, for a country to attract and sustain foreign investment, it must show that it is stable, well managed, and disciplined, with zero tolerance for corruption and maladministration, and that locals, visitors, property, and investments must be safe.

What do politicians do to fix these problems? After 25 years of ANC rule, apartheid, colonialism and racism are blamed for the poverty and the widening gap between rich and poor. The easiest way out is to expropriate property without compensation; this will help solve all problems. The socialist approach will only solve the problems of politicians to keep or gain political power in this country. It will not solve the above issues.

Mumford (1946: 327) concluded that, for a sound civilisation to function, it is not so much individual ownership of land that is important, but security of tenure. According to him, this enables continuity of use, encourages permanent improvements, and permits longrange efforts. The problem is that tenants are then in the hands of the politicians of the day.

5 In the 1904 South African census (3.9 million Blacks, 1.2 million Whites, 0.5 million Coloureds, and 0.2 million Asians), approximately 5 million people increased to roughly 58 million in 2019 (47.3 million Blacks, 4.1 million Whites, 5.1 million Coloureds, and 2.3 million Asians). This gives a growth rate of $1115 \%$ for Blacks, $241 \%$ for Whites, $940 \%$ for Coloureds, and $816 \%$ for Asians over a period of 109 years.

\subsection{Land reform and land restitution}

The ANC came into power in 1994 and embarked on a policy of state-led land reform and land restitution. The target was to redistribute $30 \%$ of White-owned land by 1999 (later moved to 2014) (McCusker et al., 2016: 2). This was a process of 'willing-buyer, willingseller'. In 2015 , only roughly $8 \%$ was redistributed and some Black farmers even sold back to White farmers (McCusker et al., 2016: 2).

Jeffery (2018), head of Policy Research at the Institute for Race Relations (IRR), found that only $8 \%$ of the 76000 successful valid land claims in 2013 wanted their land restored; the remaining $92 \%$ wanted money instead. Response to a question What is the "best way to improve lives" in 2016, the IRR also found that $73 \%$ of Black people saw "more jobs and better education" as the "best way", while only $1 \%$ thought it was "more land reform".

Hall (2009: 248) found that what distinguishes agrarian reform from land reform, is that the former goes far beyond the redistribution of land by restructuring both production and the markets. For Hall (2009: 250), it is
"on the one hand, subdivision of farming units and transfer of ownership of these to smallholder producers and on the other, the call for a stronger state role in securing tenure, including the question of whether the state should retain some role in holding land and investing public funds in administration of land rights, in order for the poor to gain access to land without the cost and risk associated with private ownership".

This is similar to Lenin's New Economic Policy, which allowed limited private enterprise, while the state retained control of the economy (Singh, 2016: 44).

Scholtz (1962: 293) describes this collectivization of land in Russia as nothing less than expropriation of land without compensation. When this did not provide enough food, Stalin (1928: 33) started his first Five-Year Plan, forcing peasants to 
surrender all livestock, machinery and land to collective farms. Up to 10 million peasants died during the famine of 1932-1933 or in the slave labour camps of the Gulag (Singh, 2016: 44). Courtois, Werth, Panné, Paczkowski, Bartošek \& Margolin (2004: 206) give a figure of 6 million people dying from famine, 720000 people executed for resisting it, and 7 million entering the Gulag. All Russian farmers became servants of the state, owning neither land nor livestock (Scholtz, 1962: 296).

Manji (2006: 141) shows that some different political issues confront Africa, a changing world where tenure must be secured, even for women, while full, private property rights can lead to indebted small farmers being replaced by agrarian business corporations. Thus "a network of land law reform, linking the local and the global in important new ways, has served to place the formalization of land relations at the centre of the new law and development" (Manji, 2006: 142).

\subsection{Economics and growth}

Jacobs (1985: 34) distinguishes between passive economies and city economies. Passive economies do not create economic change themselves but instead respond to economic forces of city economies. They can be national or rural economies that lack the all-important function of import-replacing as a function in the real life of a city.

In her book Cities and the wealth of nations, Jacobs (1985: 39) argues that "economic life develops by grace of innovating; it expands by grace of import-replacing. These two master economic processes are closely related, both being functions of city economies." Cities where import-replacing occurs release five great economic forces, namely:

- Enlarging city markets for new and different imports;

- Increased number and kind of jobs in the import-replacing city;

- Increased transplant of city work into non-urban locations as older enterprises are crowded out;
- New use of technology, particularly to increase rural production and productivity;

- The growth of city capital.

Thus, rural areas are mostly poor or rich supply regions, which are inherently overspecialised with wildly unbalanced economies that are fragile to distant markets (Jacobs, 1985: 63).

We can perhaps learn from the Taiwanese government who transferred agricultural land from ownership of feudal-like landlords to the peasants who worked the land (Jacobs, 1985: 99). The government, in paying the expropriated landlords, required that part of the payments be invested in light industry. What kind and where was left to the former landlords as long as the investment is in Taiwan (Jacobs, 1985: 101). This will help create the needed jobs in the cities as long as many of the regulations on economic development are scrapped, the country moves to a more capitalistic approach, and there is less government intervention in the economy.

\subsection{Land is more than simply land}

Land is not something like gold that has an international price that is constant to its weight (one ounce). People tend to view land as uniform, but numerous factors influence the use and value of land. Land can be used as rural farmland or urban land, with different values, depending on the location and zoning or potential use. The use of rural farmland is determined by soil type, rainfall, and climate. In some areas, 40 hectares is necessary for one sheep, while in others 40 sheep could be kept on one hectare. The price of one hectare of vineyards or other permanent crops such as pecan nuts with water rights can be up to 700 times or more than one hectare of Karoo grazing (Pienaar, 2015). Similarly, one hectare in Sandton City is worth nearly a million times more than one hectare in rural Northern Cape. Land in the former homelands of Transkei or Kwazulu, with its high rainfall, are worth many times that of the Karoo or even dryer areas on the West Coast. As a whole, out of 186 countries, South Africa is the $43^{\text {rd }}$ driest country in the world, if average rainfall is taken (Index Mundi, 2019). The country does not have an average rainfall in all areas. Some places have much more rain than others, and these differences are normally indicated in the carrying capacity per large stock unit per hectare. Thus, to say that Whites own $70 \%$ of the land area means nothing in terms of the value of the land. Water-rich areas such as Transkei (about $45000 \mathrm{~km}^{2}$ ) might be worth more than the entire Karoo (roughly 395000 km²), which is 8.7 times as big.

The farmer on the land must have the knowledge and capital to get the produce off the land. In his book The great South African land scandal, Dr Philip du Toit (2004) shows what happened to many productive farms that have been handed over under the government's restitution and redistribution programmes. These farms became desolate. He argues that South Africa needs the 35000 farmers who feed the people of this country. In Western countries, people do not demand land, although they are landless, but they are employed in other sectors. In the United States of America, farms employ only $2 \%$ of the population, while the rest of the population work elsewhere (Du Toit, 2004: 267).

\section{CONCLUSION}

South Africa cannot have a 'onesize-fits-all' solution to land. With its 11 official languages, this country needs at least as many approaches to the land issue. There should be a place for the different traditions to bloom in this country. In a less known book The question of separatism, Jane Jacobs (1981: 11-16) shows that, when the French-speaking Canadians urbanised, wealth increased and when they reached a city-sized population, culture bloomed. She found that a French culture on Canadian soil and part of the Canadian economy is not 
sustainable (Jacobs, 1981: 20-24).

Just as she believes that city states are the driving force of city economies, she also believes that peaceful and mutually beneficial separation will be good for both parties. Where cultures form city populations, they must have some form of self-determination or they will be suppressed by the majority.

Traditionalists raise their children within the family and the community, and these ties are important for them. For both Black and White traditionalists, there must be areas where they can do so. For the traditional Zulus, the Ingonyama Trust represents the embodiment of traditional Zulu land, held in the hands of their king for the Zulu nation. During a visit to KwaZulu-Natal, President Ramaphosa met with King Zwelithini and assured him that the government would not touch land under the trust (Van Diemen, 2019). Some traditional Afrikaners still believe that history is not written by man, but by God (Steÿn, 2015: 278-283). As such, they believe that future generations will continue to seek freedom for the Afrikaner among the diversity of peoples in South Africa, where every individual carries his/her own responsibility and lives according to his/her own calling.

For the creation of jobs, the country will need more capitalistic areas such as 'free cities' or 'city states' like Singapore, with low government intervention and low taxes to create jobs for neighbouring communities. There could even be areas where socialism or communism could be exercised if people choose to do so. The government must merely help and allow people who do not agree to these policies to move out of the areas they do not like.

For South Africa, this will mean considering a new political dispensation, where the country consists of different autonomous regions or city states. ${ }^{6}$ Just as the Soviet Union could not persist after

6 This means that these areas are selfgoverning and not subject to a central controlled system of land management such as SPLUMA. Each autonomous area will make its own rules, according to that area's culture and value system. the fall of communism and broke up into 15 different states, ${ }^{7}$ South Africa as a single country cannot persist after the new dispensation in 1994. Article 235 of the Constitution of the Republic of South Africa allows for self-determination:

"235. Self-determination. The right of the South African people as a whole to self-determination, as manifested in this Constitution, does not preclude, within the framework of this right, recognition of the notion of the right of self-determination of any community sharing a common cultural and language heritage, within a territorial entity in the Republic or in any other way, determined by national legislation" (RSA, 1996: 31).

South Africa could identify and delineate several formal and functional regions, according to Glasson's (1978: 39) definition of a planning region where each should be "an area which is large enough to enable substantial changes in distribution of population and employment to take place within its boundaries, yet which is small enough for its planning problems to be seen as a whole".

There should be a variety of possibilities from which the population can choose. People can then join whichever solution they support or earn money in one area and live in another. Thus, a South Africa consisting of different regions or city states, each being autonomous to choose which ideology is important for the group concerned. Planners need to help expose the limits of possibilities in this instance. This will leave room for the different role players in the country to have a niche of their own.

\section{REFERENCES}

AITCHISON, J. 2018. SA's reading crises is a 'cognitive catastrophe'. Saturday Star, 28 February 2018, p. 8.

ARMSTRONG, S. 2010. The superrich shall inherit the earth. London: Constable \& Robinsons Ltd.

7 The Republic of Estonia is roughly the same size as the old Transkei, with a much smaller population, whereas Latvia and Lithuania are both slightly larger, with a smaller and a similar population size, respectively.
BAUDET, T. \& VISSER, M. 2017

Conservatiewe vooruitgang.

Amsterdam: Prometheus.

BEATLEY, T. 1994. Ethical land use: Principles of policy and planning. London: John Hopkins University Press.

BOUCKAERT, B. (Ed.). 2010. Property law and economics. Cheltenham: Edward Elgar.

BUNDY, C. 1988. The rise and fall of the South African peasantry. London: James Currey Publishers.

CASTELLS, M. 1992. The world has changed: Can planning change? Landscape and Urban Planning, 22, pp. 73-78.

COMPTON, R. 2018. Migration and integration as South Africa's regional challenges. Personal notes taken of paper delivered at the Regional Studies Association Winter Conference on New Horizons for Cities and Regions in a Changing World, 15-16 November 2018, London.

COURTOIS, S., WERTH, N., PANNÉ, J., PACZKOWSKI, A., BARTOŠEK, K. \& MARGOLIN, J. 2004. The black book of communism: Crimes, terror, repression ( $5^{\text {th }}$ printing). London: Harvard University Press.

DIAMOND, J. 2006. Zwaarden, paarden en ziektekiemen: De ongelijkheid in de wereld verklaren. ( $7^{\text {th }}$ revised edition) (Translated from the English title: Guns, germs and steel: The fates of human societies). Utrecht: Uitgeverij het Spectrum.

\section{DOE (DEPARTMENT OF}

EDUCATION). 2005. History of the Freedom Charter. [Online]. Available at: <https://www.environment.gov.za/ sites/default/files/docs/publications/ history_freedomcharter.pdf> [Accessed: 29 October 2019].

DU TOIT, P. 2014. The great South African land scandal. Centurion: Legacy Publications.

GLASSON, J. 1978. An introduction to regional planning. London: Hutchinson.

GOUDAPPEL, H.M. 1985. Urbanistics: A way to a new understanding of man's relationship with the environment. Man-Environment Systems, 15(5\&6), pp. 179-184.

GUMEDE, M. 2017. Students were better off in the 1980s, says Statistics chief. Business Day, 25 October 2017. 
HALL, P. 2002. Planning the millennial prospect. Town and Regional Planning, 45, pp. 5-11.

HALL, R. (Ed.). 2009. Another countryside? Policy options for land and agrarian reform in South Africa. Bellville, PLAAS, University of the Western Cape.

HUNT, P.M.A. 1973. Law of property. In: Potgieter, D.J. (Ed.). Standard Encyclopedia of Southern Africa, volume 9. Cape Town: Nasou Limited.

INDEX MUNDI. 2019. Average precipitation in depth ( $\mathrm{mm}$ per year) Country Ranking. [Online]. Available at: <https://www.indexmundi.com/ facts/indicators/AG.LND.PRCP.MM/ rankings> [Accessed: 18 July 2019].

IMF (INTERNATIONAL MONETARY FUND). 2019. IMF DataMapper: Inflation rate. [Online]. Available at: https://www.imf.org/external/ datamapper/PCPIPCH@WEO/ OEMDC/ [Accessed: 12 July 2019].

JACOBS, J. 1981. The question of separatism: Quebec and the struggle over sovereignty. New York: Vintage Books.

JACOBS, J. 1985. Cities and the wealth of nations. New York: Vintage Books.

KRUGER, P. 2016. Settlement of the Boer-Afrikaner people's claim to territorial self-determination: Inviting international intervention. Pretoria: Paul Kruger.

MANJI, A. 2006. The politics of land reform in Africa: From communal tenure to free markets. London: Zed Books.

MARX, K. \& ENGELS, F. 1989a. Karl Marx and Frederick Engels Selected Works in three volumes - Volume One. (6 $6^{\text {th }}$ revised printing). Moscow: Progress Publishers.

MARX, K. \& ENGELS, F. 1989b. Karl Marx and Frederick Engels Selected Works in three volumes - Volume Two. (6 $6^{\text {th }}$ revised printing). Moscow: Progress Publishers.

MCCUSKER, B., MOSELEY, W. \& RAMUTSINDELA, M. 2016. Land reform in South Africa: Uneven transformation. Lanham, MD: Rowman \& Littlefield.

MCQUAIG, L. \& BROOKS, N. 2013. The trouble with billionaires: How the super-rich highjacked the world (and how we can take it back). London: Oneworld Publications.
Mthethwa, T. 2013. Enhancing systems

of functional internal controls and governance process to overcome fraud and corruption in the public service. Paper delivered at IMFO Annual Audit \& Risk Indaba, East London, 21-23 May 2014.

MUMFORD, L. 1946. The culture of cities. London: Secker \& Warburg.

NIJKAMP, P. 1980. Herfsttij der vooruitgang. Groningen: De Vuurbaak.

OXFAM (Oxford Committee for Famine Relief). 2016. An economy for the $1 \%$ : How privilege and power in the economy drive extreme inequality and how this can be stopped. Oxford: Oxfam Briefing Paper 210, 18 January 2016.

\section{OXFAM (Oxford Committee for} Famine Relief). 2017. Oxfam. Just 8 men own same wealth as half the world. [Online]. Available at: <https:// www.oxfam.org/en/pressroom/ pressreleases/2017-01-16/just-8men-own-same-wealth-half-world> [Accessed: 16 January 2017].

PAUW, B.A. 1970. Bantu. In: Potgieter, D.J. (Ed.). Standard encyclopedia of Southern Africa, volume 2. Cape Town: Nasou Limited.

PIENAAR, P. 2015. Farm valuations in practice. Jeffries Bay: Agri Land Price Index (Pty) Ltd.

RSA (REPUBLIC OF SOUTH AFRICA). 1996. Constitution of the Republic of South Africa Act, Act 108 of 1996. Pretoria: Government Printer.

SCHOLTZ, G.D. 1962. Die stryd om die wêreld: Rusland en die kommunisme. Johannesburg: Voortrekkerpers Bpk.

SCOTT, A. 2008. The evolution of resource property rights. Oxford: Oxford University Press.

SINGH, M.M. (Ed.). 2016. DK eyewitness travel Russia. London: Penguin Random House.

STEŸN, J.J. (Ed.). 2011. Hendrik M. Goudappel: Mobility and space, volume 2, Reader on urbanistics and planning. (Published only in Dutch as "Hendrik M. Goudappel: Mobiliteit en ruimte, volume 2, 'Reader' over de urbanistiek en planologie). Deventer, The Netherlands: Goudappel Coffeng.
STEŸN, J.J. 2014. Confronting the power of the babblers and the billionaires is necessary to make South Africa a great place. In: Conference Proceedings: Planning Africa 2014 - Making Great Places, 19-22 October 2014. Johannesburg: SAPI, pp. 267-278.

STEŸN, J.J. 2015. Reforming normative planning: Essays on a Christian approach to planning. Orania: Prisca Uitgewers.

TUROK, I. 2019. Cities as platforms for progress: Local drivers of Rwanda's success. Local Economy, 34(3), pp. 221-227.

VAN DEN BERG, J.H. 1989. Hooligans: Metabletish onderzoek naar de betekenis van Centre Pompidou en Crystal Palace. Nijkerk: Callenbach.

VAN DER BORGHT, E. 2009.

"The God-given land": Religious perspectives on land reform in South Africa. Amsterdam: Rozenberg Publishers.

VAN DIEMEN, E. 2019. Ramaphosa says no 'arbitrary action' on Ingonyama Trust land. Panel report still being scrutinised. [Online]. Available at: <https://www.news24.com/SouthAfrica/ News/ramaphosa-says-no-arbitraryaction-on-ingonyama-trust-land-panelreport-still-being-scrutinised-20190822> [Accessed: 29 October 2019].

VAN NIEKERK, A. 1982. Dominee, are you listening to the drums? Cape Town: Tafelberg Publishing Ltd.

VAN NIEKERK, A. 1993a. Dreunsang deur die nuwe Afrika: Grond! Grond! Rapport, 1993.

VAN NIEKERK, A. 1993b. One destiny: Our common future in Africa. Cape Town: Tafelberg Publishing Ltd.

VERBRUGH, A.J. 1985. Universeel en antirevolutionair: Toelichting by de richtlijnen voor de nationalgereformeerde, dat is universeelchristelijke en antirevolutionaire politiek. Volume III. Groningen: Uitgeverij De Vuurbaak bv.

VORHIES, F. 1991. Comprehending Karl Marx. Kenwyn: Juta \& Co. Ltd.

WALTER, E. (Ed.). 2009.

The Cambridge advanced learner's dictionary. $3^{\text {rd }}$ edition. Cambridge: Cambridge University Press. 